\title{
Registered Dietitian
}

National Cancer Institute

\section{Source}

National Cancer Institute. Registered Dietitian. NCI Thesaurus. Code C71277.

An individual who: (1) has completed the minimum of a Baccalaureate degree granted by a U.S. regionally accredited colleg o or university, or equivalent; (2) has met current minimum academic requirements (Didactic Program in Dietetics) as approved by the Commission on Accreditation/Approval for Dietetics Education of the American Dietetic Association; (3) has completed pre-professional experience accredited/approved by the Commission on Accreditation/Approval for Dietetics Education of the American Dietetic Association; (4) has successfully completed the Reg istration Examination for Dietitians; (5) has the annual registration maintenance fee; and (6) has accrued 75 hours of approved continuing professional education within a specific five-year reporting period. 